\title{
OS RABELADOS DE CABO VERDE, UM “QUILOMBO” AFRICANO
}

\author{
Hilton P. Silva ${ }^{1}$
}

\section{O Conhecendo os Rabelados}

Bem ao norte da Ilha de Santiago, no arquipélago de Cabo Verde, situa-se a zona de Espinho Branco, no "Concelho de São Miguel", a aproximadamente $80 \mathrm{~km}$ da capital, Praia. Este município guarda a mais tradicional, isolada e ainda pouco conhecida comunidade do país: Os Rabelados.

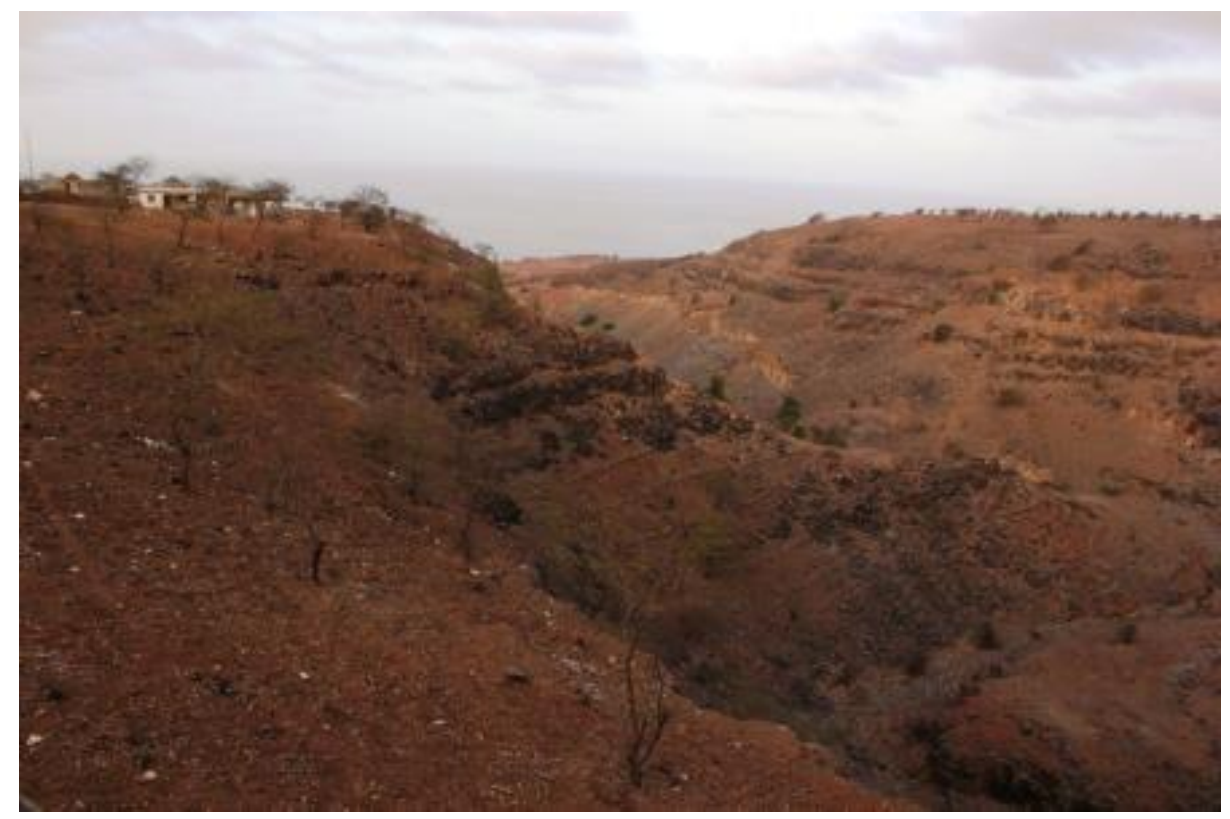

A paisagem árida de Espinho Branco. Fonte: Hilton P. Silva.

\footnotetext{
${ }^{1}$ Universidade Federal do Pará, Brasil.
}

Iluminuras, Porto Alegre, v. 17, n. 41, p. 340-358, jan/jun, 2016. 


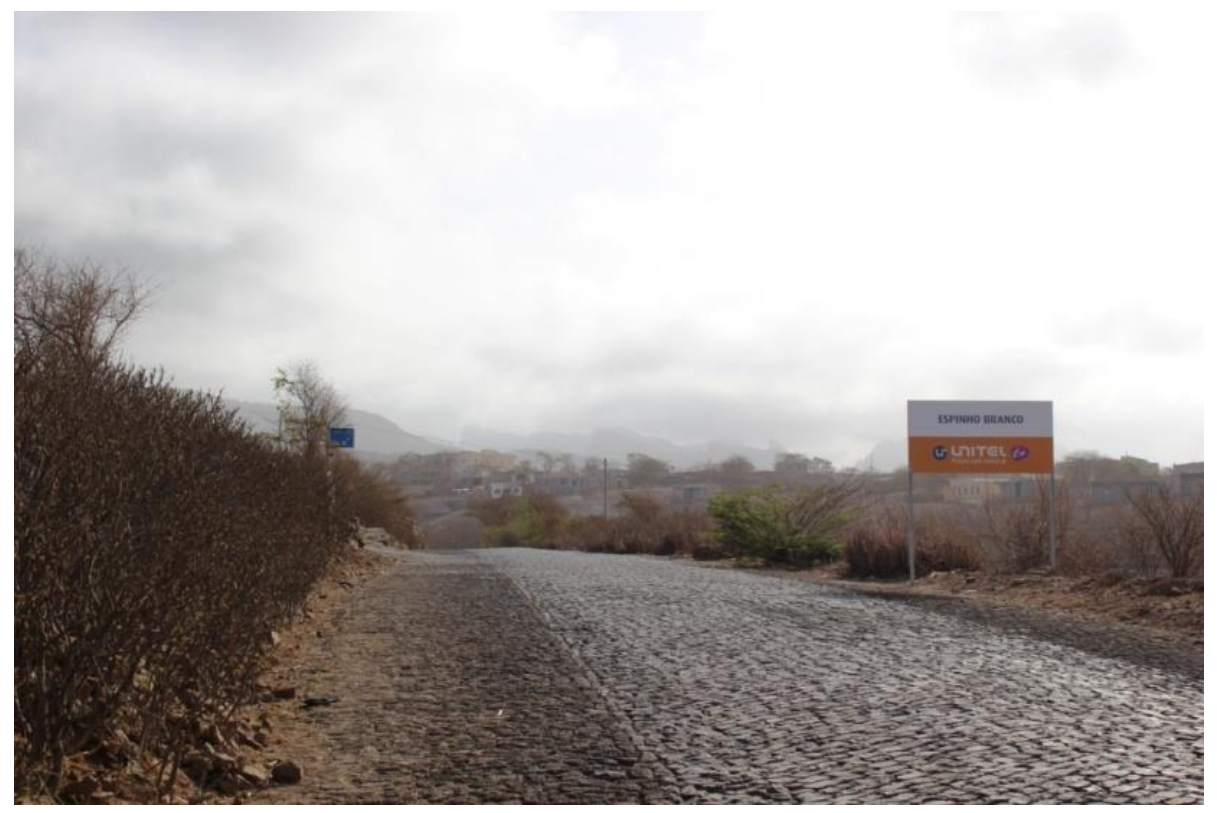

Estrada de Espinho Branco. Fonte: Hilton P. da Silva.

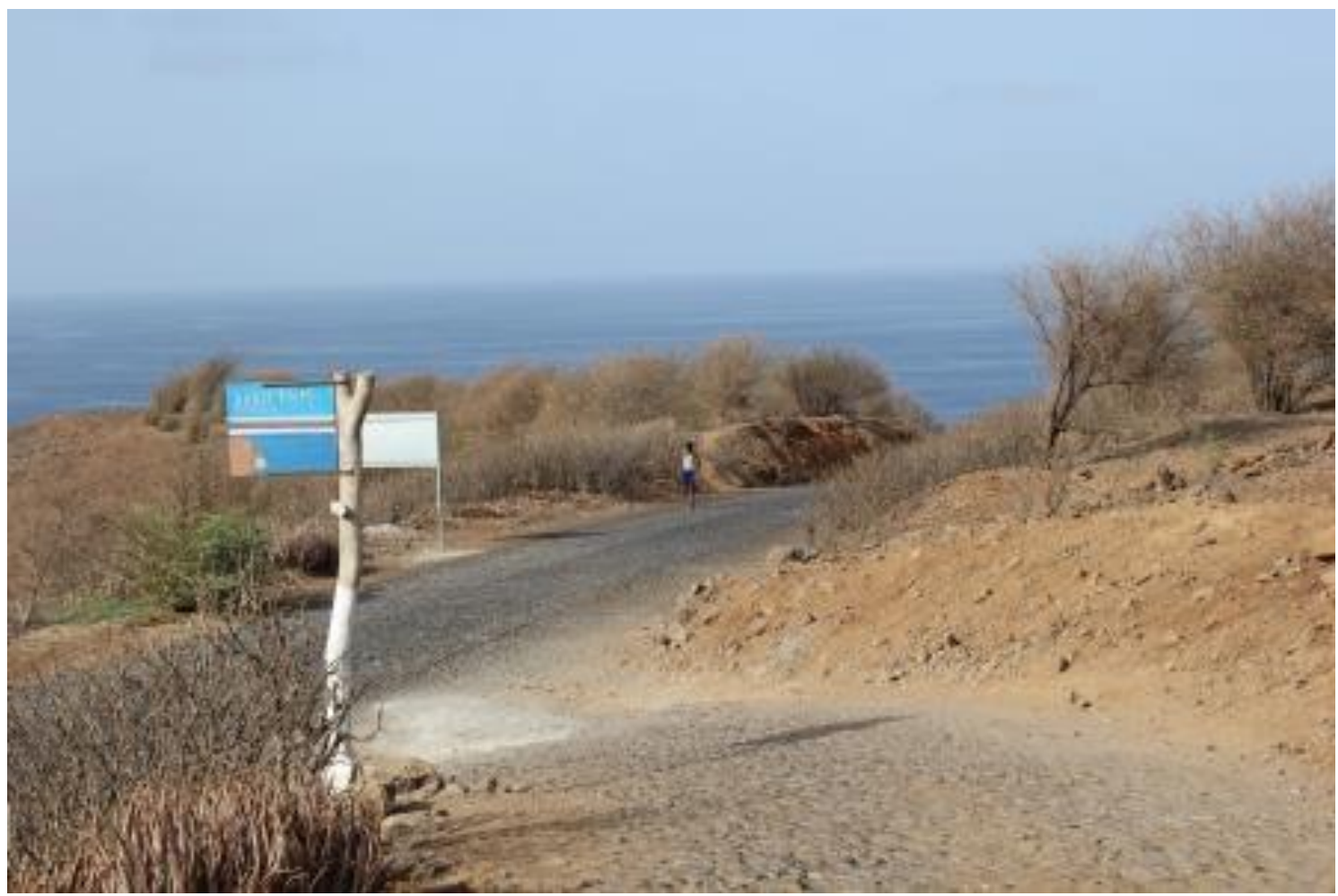

O mar dos Rabelados. Fonte: Hilton P. Silva.

Iluminuras, Porto Alegre, v. 17, n. 41, p. 340-358, jan/jun, 2016. 
Em julho de 2015, fui convidado para participar de uma oficina da Universidade Popular dos Movimentos Sociais (UPMS) ${ }^{2}$ em Cabo Verde, uma iniciativa do Instituto Universitário de Educação (IUE) daquele país em parceria com a Universidade da Integração Internacional da Lusofonia Afro-Brasileira (UNILAB), o Centro de Estudos Sociais da Universidade de Coimbra (CES/UC), o Projeto Alice da Universidade de Coimbra e a Faculdade Latinoamericana de Ciências Sociais no Brasil (FLACSO/Brasil), entre outros parceiros nacionais e internacionais. A oficina teve como foco a comunidade dos Rabelados ${ }^{3}$. A proposta de criação da UPMS teve origem com o Prof. Dr. Boaventura de Sousa Santos, Catedrático da Faculdade de Economia da Universidade de Coimbra, durante o Fórum Social Mundial (FSM) de 2003 (Santos, 2006). Diversas oficinas têm ocorrido desde então envolvendo entidades educacionais não governamentais, oficiais e comunidades vulnerabilizadas em vários lugares do mundo ${ }^{4}$. No ano em que Cabo Verde comemorou seus 40 anos de independência, os organizadores consideraram de grande importância a realização de uma Oficina da UPMS em torno da educação, seus sentidos para o desenvolvimento e as possibilidades de alternativas emancipatórias neste país, que tem investido esforços consideráveis na universalização do ensino. Parte das minhas atribuições era registrar as atividades através de fotografias e contribuir com uma perspectiva antropológica sobre as discussões em pauta. Acabei por descobrir um universo social que transita entre o presente e o passado, e que tenta se localizar na busca de um futuro melhor para seus integrantes algo que, para mim, pareceu muito semelhante à situação vivida pelas populações quilombolas com as quais venho trabalhando no Pará acerca de uma década.

Através de uma abordagem lastreada na Antropologia Visual, este artigo fotográfico objetiva desvelar um pouco do cotidiano, das práticas, condições de vida e das relações dos Rabelados com o seu meio ambiente, com a intenção de ilustrar as semelhanças socioeconômicas e etno-históricas entre eles e os remanescentes de quilombos que vivem em áreas rurais brasileiras, considerando o enorme potencial narrativo da imagem, que permite ao leitor-observador ir além da interpretação oferecida pelo autor, e escolher seu próprio caminho para a apreensão dos fenômenos etnografados, sejam eles sociais, ambientais, culturais ou ecológicos.

\footnotetext{
${ }^{2}$ http://www.universidadepopular.org/site/pages/pt/sobre-a-upms.php

${ }^{3}$ http://www.rtc.cv/tcv/index.php?paginas $=45 \&$ id_cod=42451

${ }^{4}$ http://www.universidadepopular.org/site/pages/pt/em-destaque.php
} 


\section{Quem são os Rabelados}

Atualmente os Rabelados formam um grupo de cerca de 450 pessoas, a maioria crianças, mas também muitos jovens e idosos, que vivem em um mundo quase a parte do resto do país. Eles moravam antes espalhados nas íngremes montanhas ao redor e se congregaram neste local do Espinho Branco em 2000, sob a liderança de Nho Agostinho, que morreu com idade ignorada em 2006. Embora alguns ainda permaneçam em outros locais, nesta área de mais fácil acesso eles (re)construíram suas casas, cercas e manjedouras, em um estilo que muito lembra as descrições da literatura sobre comunidades medievais europeias. Sobrevivem principalmente da agricultura, criação de pequenos animais, pesca e artesanato. Este último introduzido recentemente pela artista plástica Maria Isabel Alves, a Misá. Renomada na Europa, esta Caboverdiana passou grande parte de sua vida na Suíça, até que há alguns anos resolveu largar tudo e buscar as raízes em seu país de nascimento. Segundo ela, em uma visita ao interior de Santiago encontrou os Rabelados em situação de abandono social e abraçou sua causa. Misá tem sido a principal responsável pela divulgação da comunidade, suas necessidades e especificidades, suas demandas e anseios, dentro e fora de Cabo Verde. Ela ajudou na organização de uma associação local de artistas chamada Rabel-Arte e tem treinado muitos jovens em diversos caminhos das artes plásticas, mostrando a beleza existente em seu cotidiano, nas paisagens locais e resgatando a autoestima deste grupo, que foi segregado e caçado no passado, e ainda hoje continua discriminado ${ }^{5}$.

\footnotetext{
${ }^{5}$ https://pt.wikipedia.org/wiki/Rabelados
} 


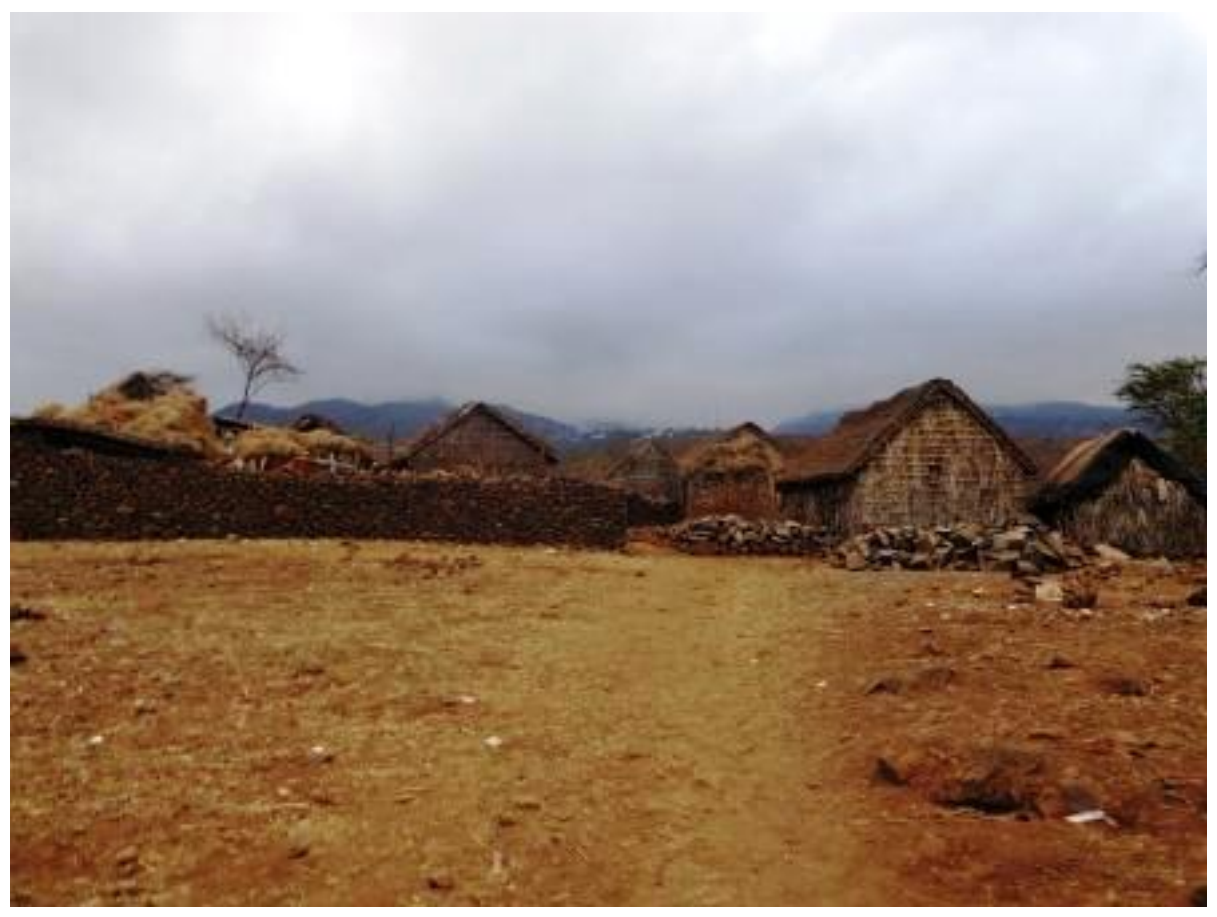

A comunidade dos Rabelados. Fonte: Hilton P. Silva.

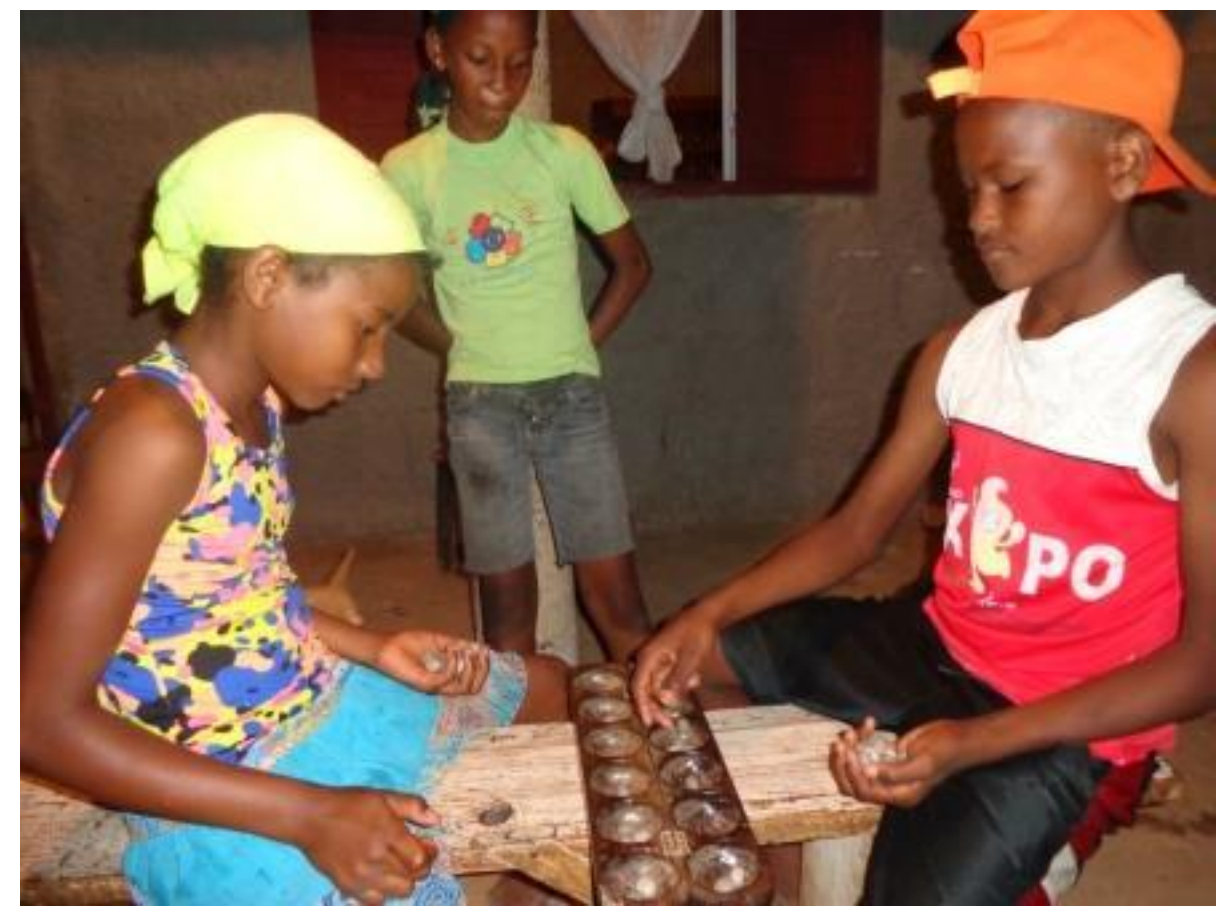

Crianças jogando gamão. Fonte: Hilton P. Silva. 


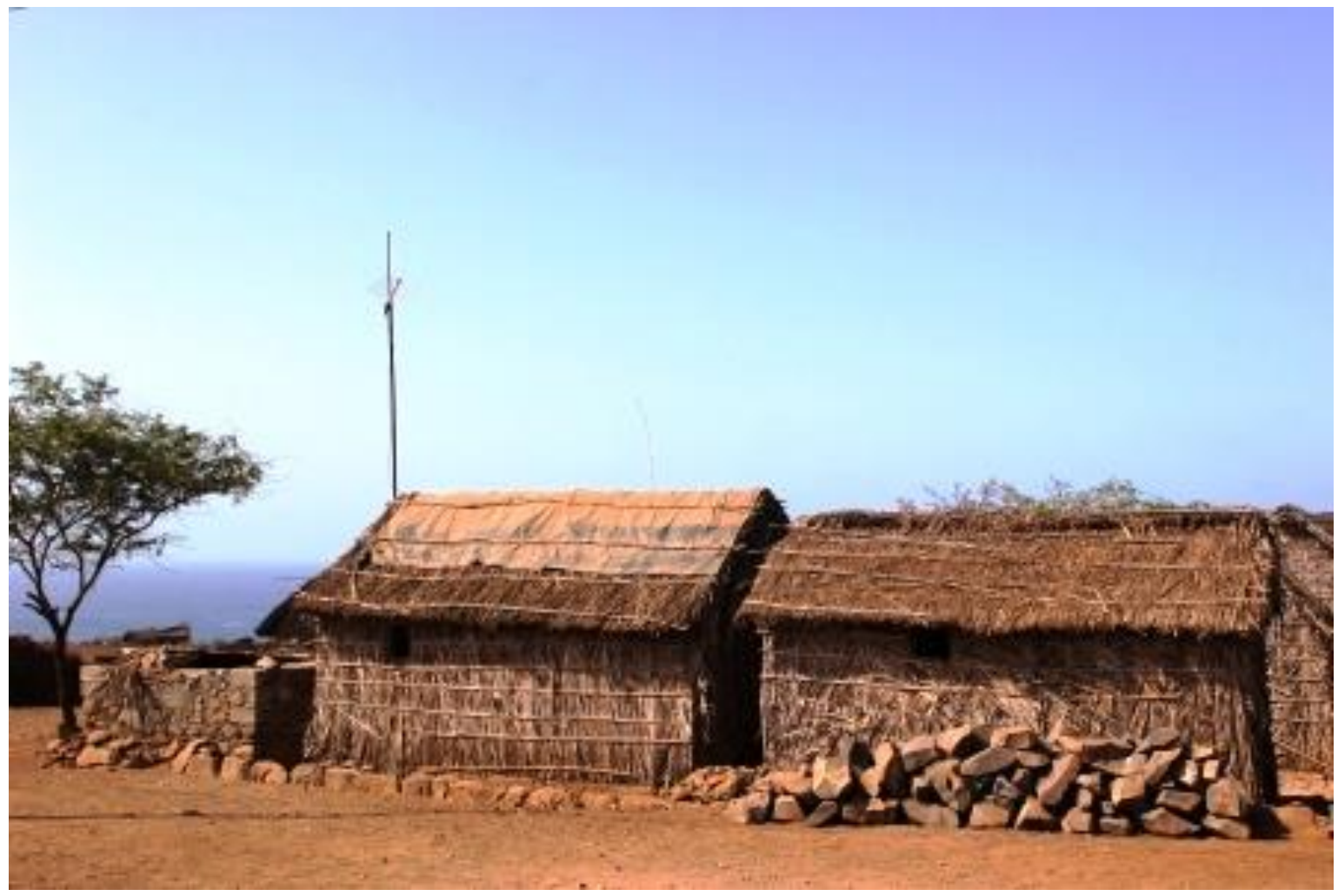

Casas tradicionais dos Rabelados. Fonte: Hilton P. Silva.

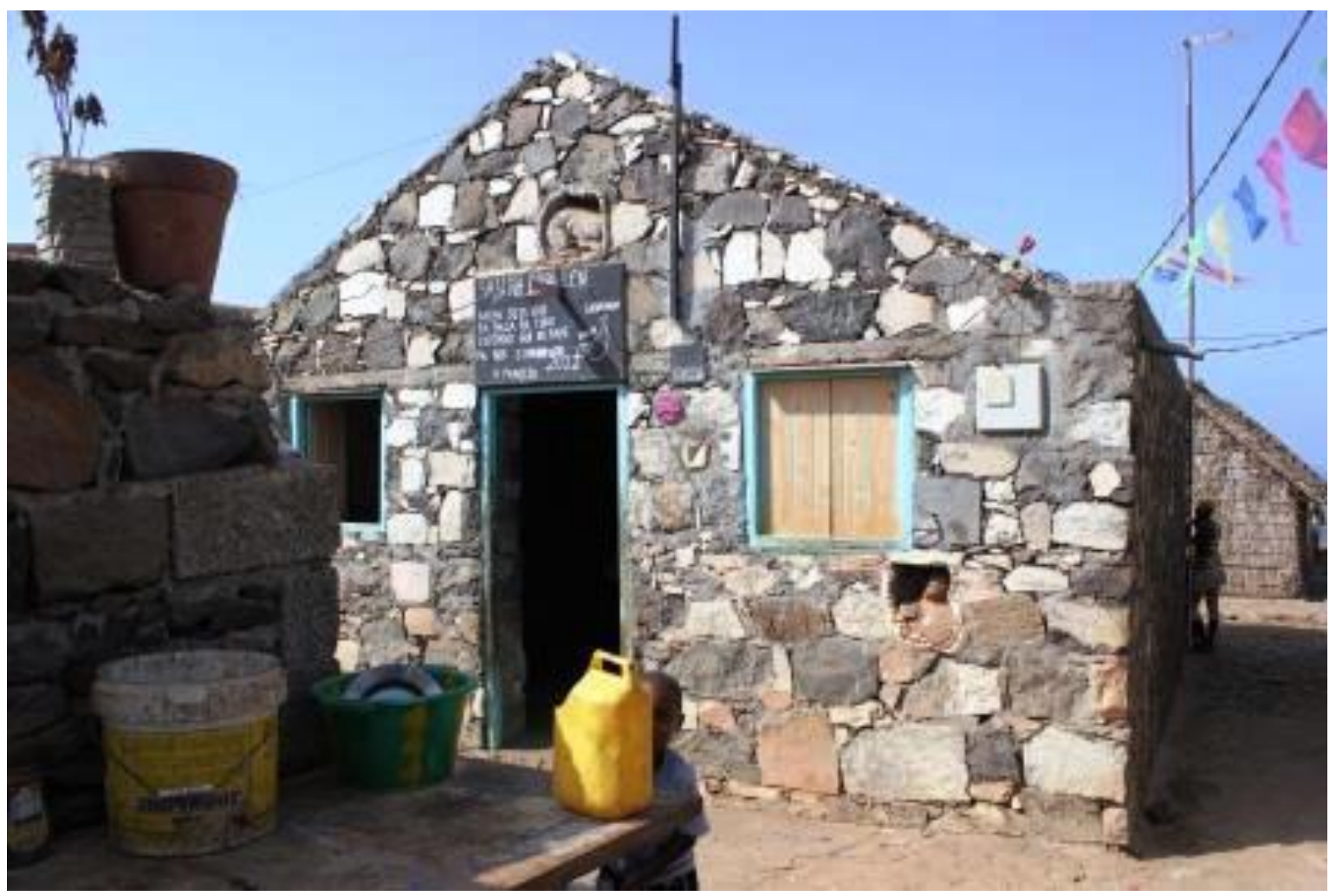

Casa feita de pedra. Fonte: Hilton P. Silva. 


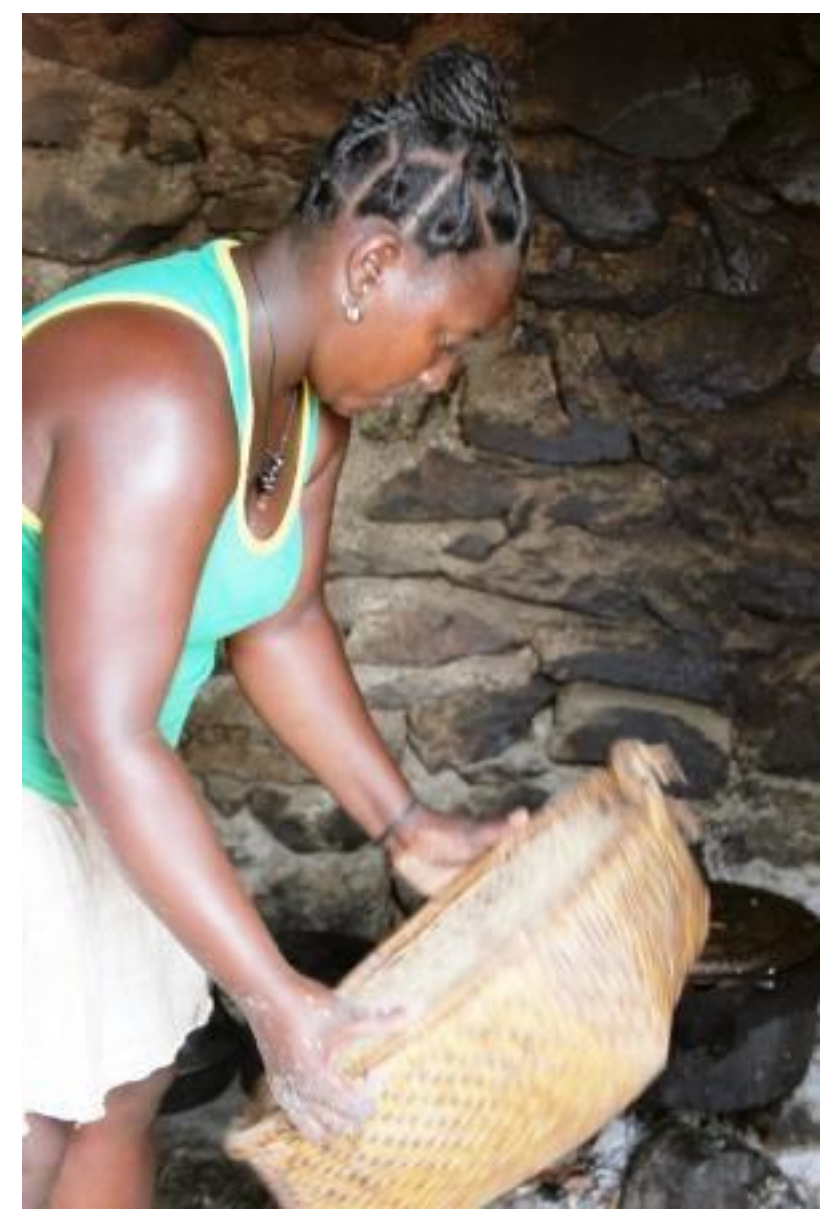

Agricultora Rabelada. Foto: Hilton P. Silva.

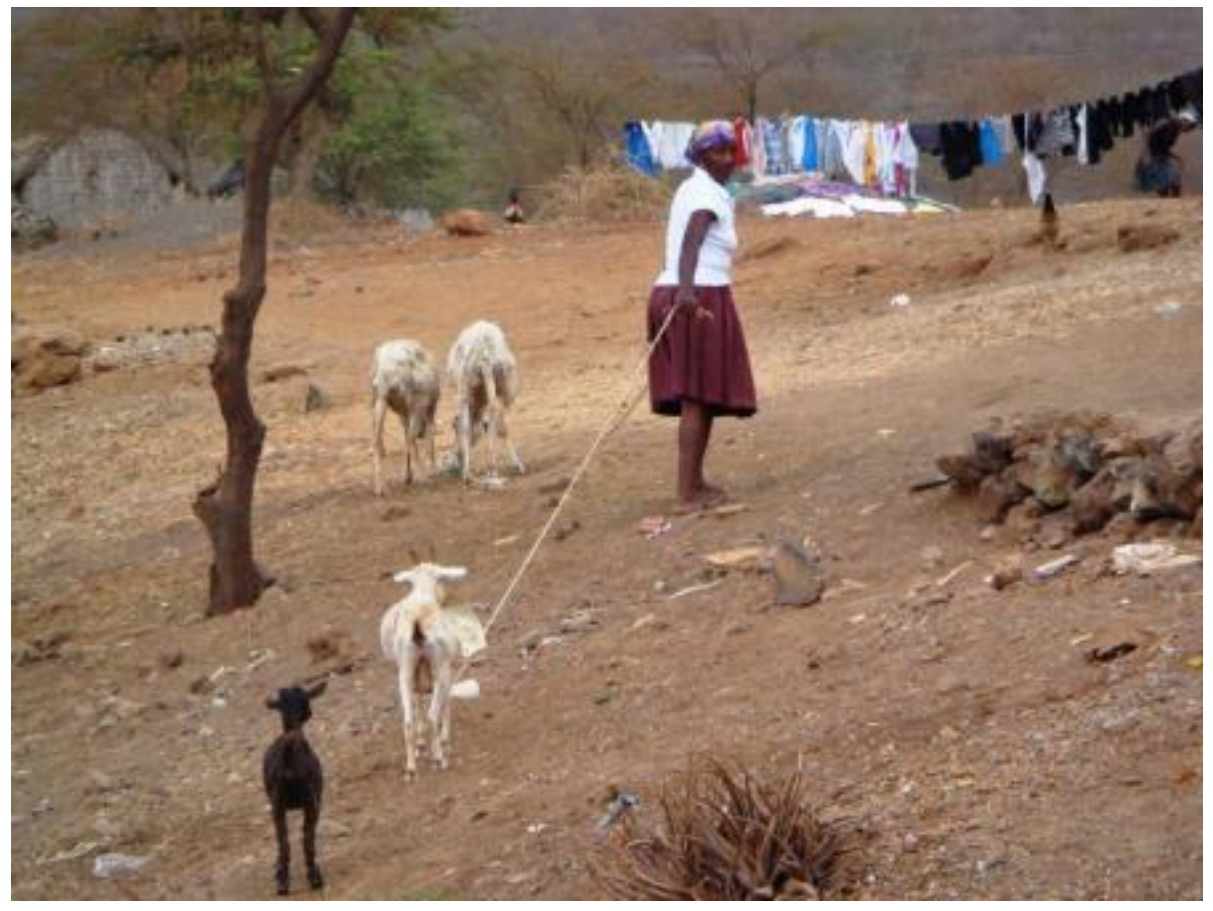

Rabelada pastoreando cabras. Fonte: Hilton P. Silva. 


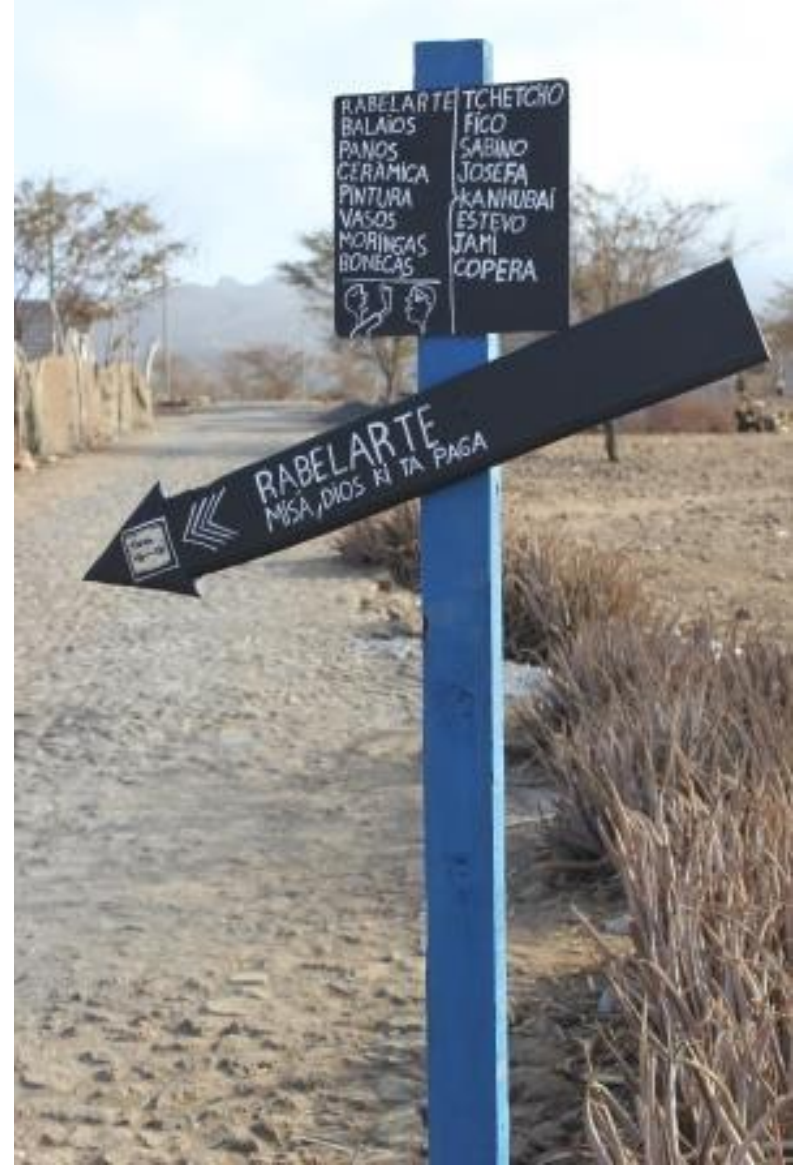

Sinal da Associação Rabel - Arte na entrada da comunidade. Fonte: Hilton P. Silva.

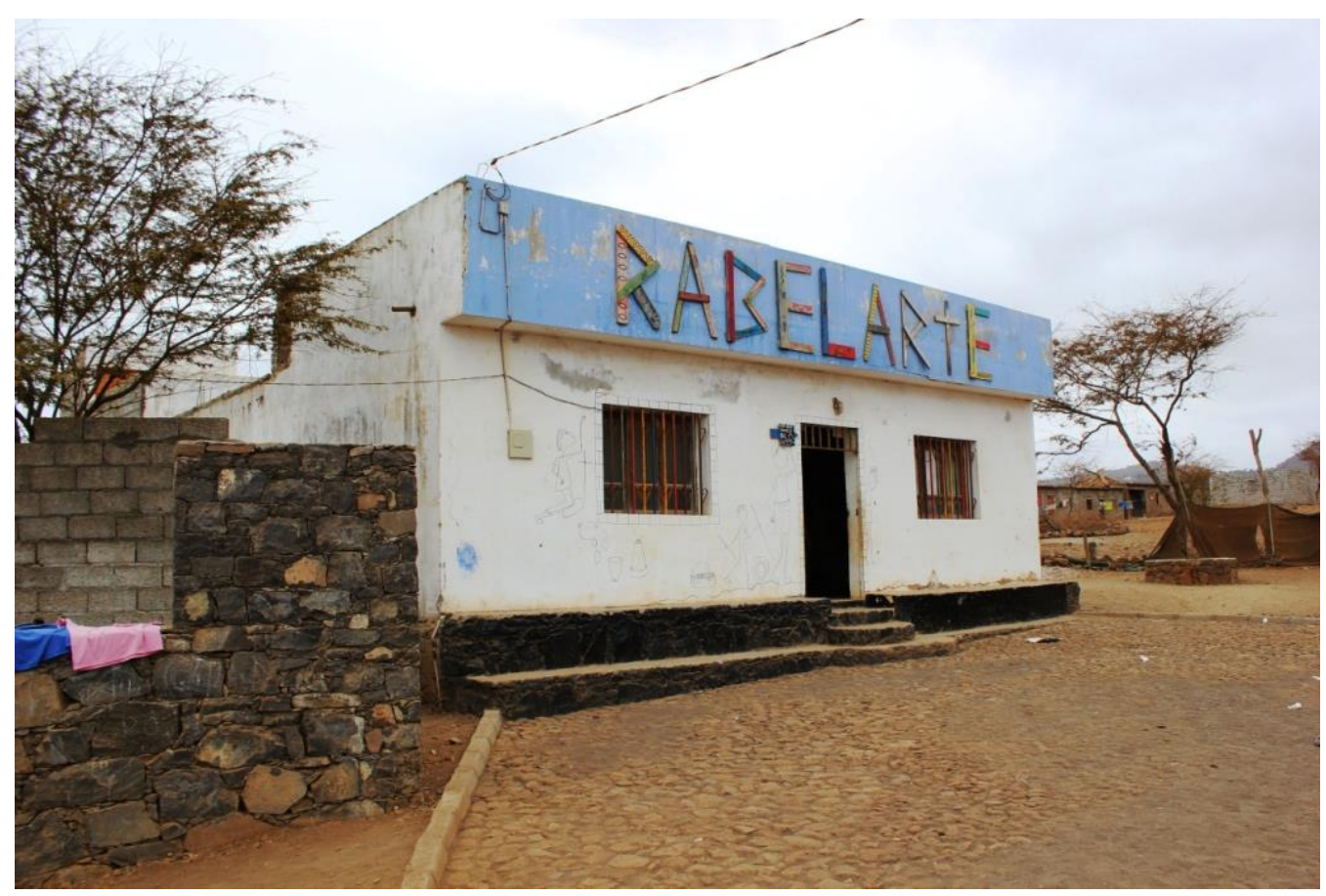

Associação Rabelarte. Fonte: Hilton P. Silva. 


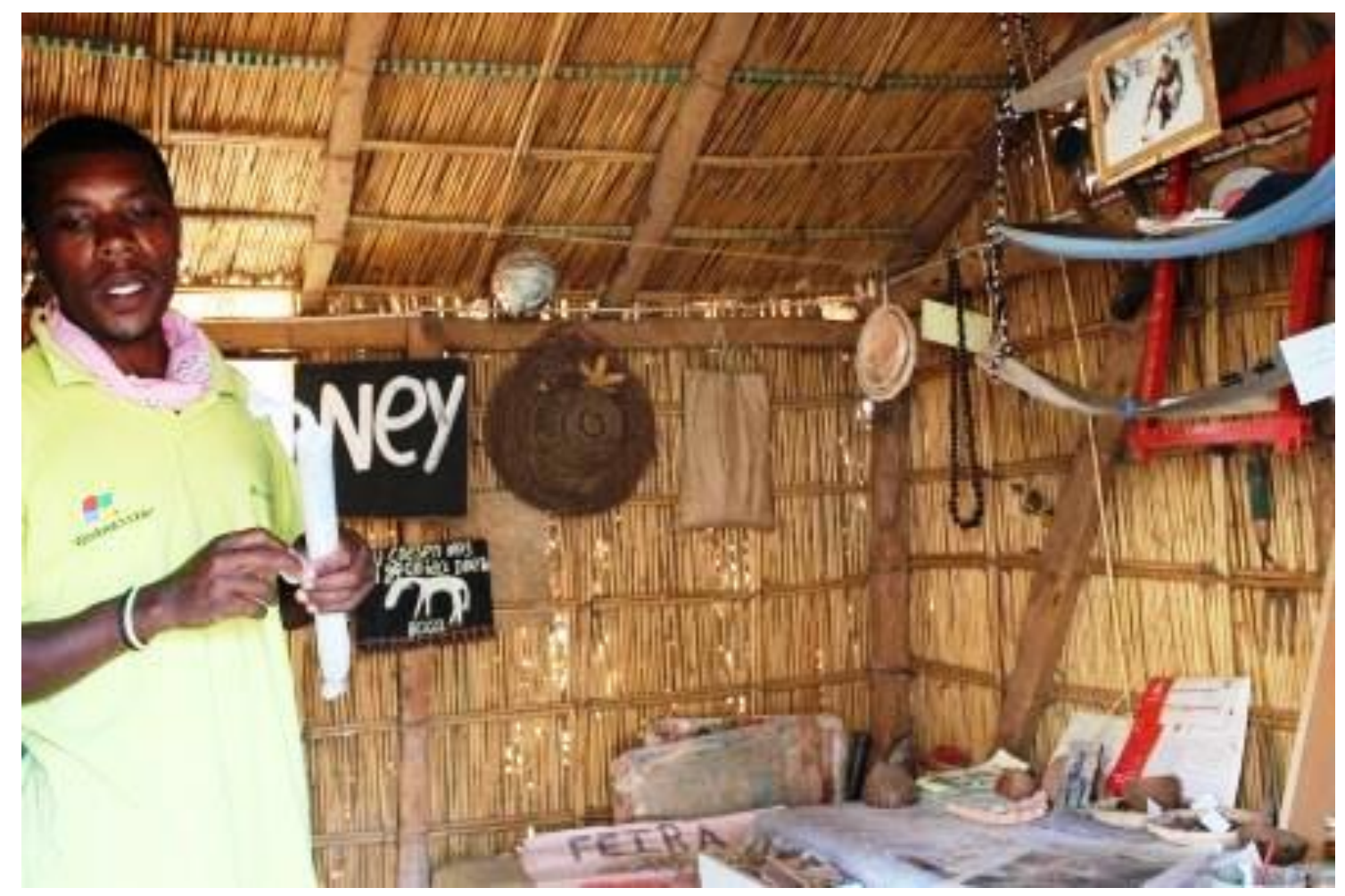

Artista Rabelado e seu estúdio. Fonte: Hilton P. Silva.

\section{A Origem dos Rabelados}

A história dos Rabelados data da década de 1940, quando chegou a Cabo Verde uma leva de padres da Consagração do Espírito Santo para substituir os "padres da terra", padres negros locais, que haviam sido ordenados desde o final do século XVII para suprir a carência de evangelizadores europeus na então colônia portuguesa. Os "padres pretos", como também eram conhecidos, seguiam tradições católicas ancestrais, como a missa, a bíblia e outros livros sagrados em Latim, normas rígidas sobre o vestir e se comportar, uma intensa doutrinação sobre a penitência, a pobreza e o desprezo aos bens materiais para a aquisição da vida eterna, e também cultivavam relações muito próximas com os fiéis (segundo relatos históricos alguns eram polígamos e tinham vários filhos nas suas diversas paróquias). Por todas essas razões, a cúpula eclesial na metrópole decidiu substituí-los por padres vindos da Europa. Estes, curiosamente, além de serem brancos, se vestiam de branco e falavam Português, em oposição aos "padres da terra" que se vestiam de preto e falavam crioulo. Houve então uma divisão entre os fiéis, instigado por alguns dos antigos padres, e muitos devotos se recusaram a aceitar a 
nova autoridade e prática eclesial, criando seus próprios grupos para manter as tradições (Asher, 2011).

O nome pelo qual se autoidentificavam originalmente era "Revelados", pois consideravam que suas práticas e crenças lhes revelavam a verdadeira e original doutrina cristã. Por resistirem aos novos modos e comandos vindos de fora, foram ridicularizados e perseguidos pela igreja e pelo poder público, que os tinha como um potencial perigo de insurreição social devido ao seu pensar dissidente e coletivista, considerado por muitos, especialmente durante a década de 1960, período da guerra de independência de Guiné-Bissau e Cabo Verde, como de orientação comunista e anticolonial. Vários foram presos, torturados e desterrados para outras ilhas e muitas famílias se dispersaram pelas escarpas íngremes da principal ilha do arquipélago. Neste período, Revelados então se tornou, em Português continental, Rebelados e, posteriormente, em crioulo, a língua geral do país, Rabelados, nome pelo qual passaram também a se autoidentificar em anos recentes (Júnior, 1974; Monteiro, 1974).

\section{Como Vivem os Rabelados}

Em um processo muito similar ao ocorrido com as comunidades quilombolas amazônidas, cimarrones e palenques do Peru, Colômbia e Panamá, e outras formadas por escravizados que fugiam do cativeiro nas Américas em virtude das perseguições contínuas e para sobreviver (Salles, 2005; Jaramillo, 2009), famílias inteiras se refugiaram em áreas remotas e de difícil acesso da Ilha de Santiago, principalmente nas regiões montanhosas de Tarrafal e Santa Cruz. Em situação de quase total isolamento por muitos anos conseguiram, então, preservar suas tradições religiosas, culturais e modos ancestrais de vida. Antigamente eles recusavam qualquer tipo de modernidade, como andar de carro, ter rádio, televisão, eletricidade e mesmo educação formal (Júnior, 1975). Porém, recentemente, quando os mais jovens assumiram a liderança, gradualmente essa situação mudou, intensificando-se a busca pelas conexões com o mundo exterior (Évora, 2011). Atualmente as crianças estão matriculadas no sistema formal de ensino (embora ainda tenham muita dificuldade para chegar à escola secundária e lá sejam frequentemente discriminadas), foi construída uma escola de ensino fundamental na comunidade, há eletricidade e aparelhos domésticos como televisão e rádio, bem como telefones celulares em algumas residências, principalmente 
daqueles que tem se envolvido com as atividades de recepção de turistas, confecção e venda de artesanato, que lhes rende financeiramente e os destaca na sociedade, uma vez que alguns, como o atual líder, Tchetcho, até já participaram de exposições na Europa. Mas a missa tradicional, a leitura das escrituras aos domingos e o jejum, juntamente com a forte tradição milenarista de história oral, inclusive de músicas sacras antigas, e a idolatria ao líder revolucionário Amílcar Cabral, fundador do Partido da Independência de Guiné e Cabo Verde (PAIGC) e à bandeira original do partido, ainda são parte fundamental da vida social e comunitária, cuidadosamente preservados por Seu Felix, o mais velho da comunidade. Em 2014, em um exemplo de grande superação pessoal e apoio da coletividade, formou-se na universidade a primeira mulher Rabelada ${ }^{6}$. A jovem Maria de Jesus, conhecida como Zy, recebeu o diploma de contabilidade de uma faculdade particular local e agora busca se inserir no mercado formal de trabalho em Santiago, ou cursar um mestrado no Brasil.

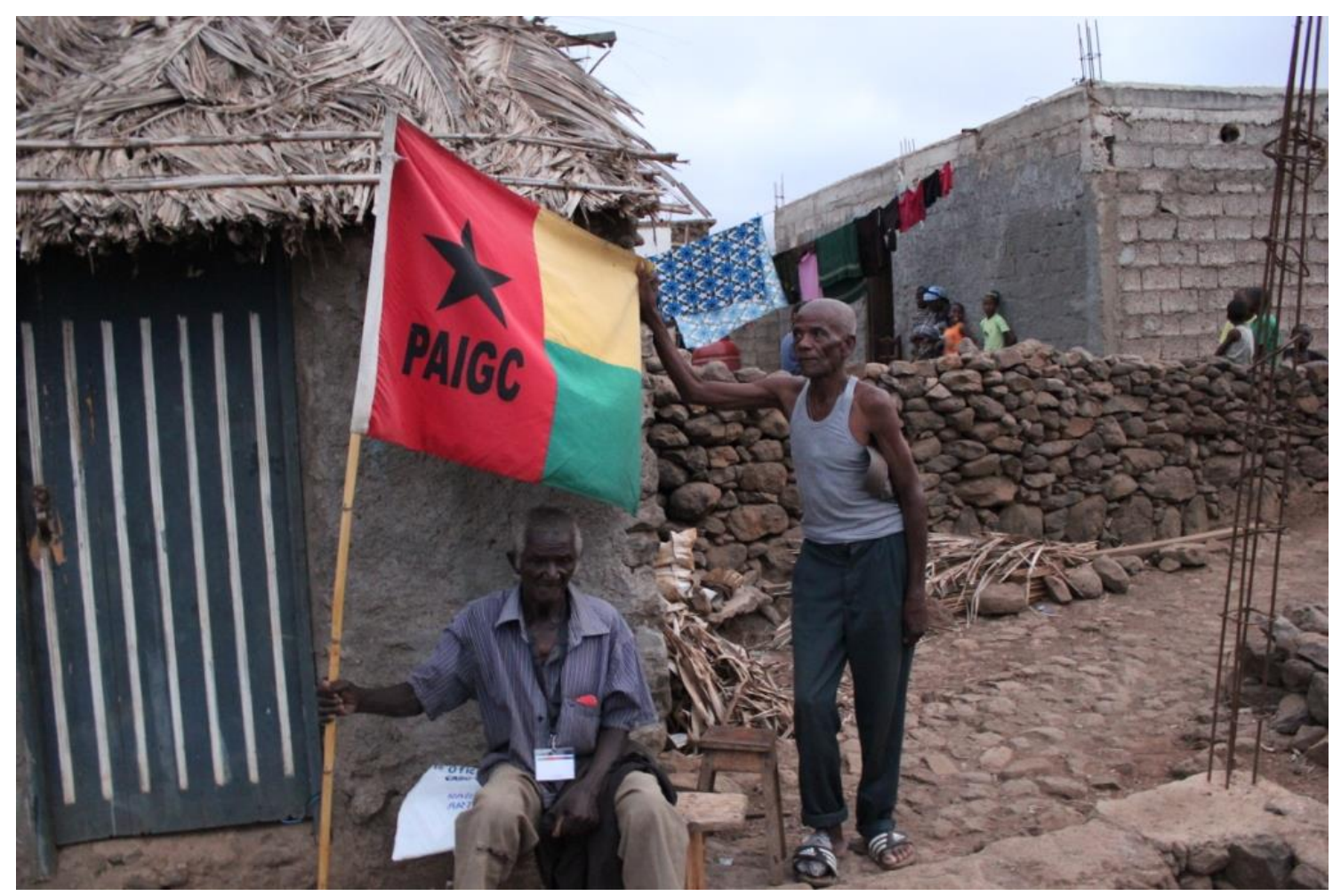

Felix e Domingos e a bandeira original do Partido da Independência de Guiné-Bissau e Cabo Verde. Fonte: Hilton P. Silva.

\footnotetext{
${ }^{6}$ http://www.rtc.cv/tcv/index.php?paginas=13\&id_cod=34756
} 


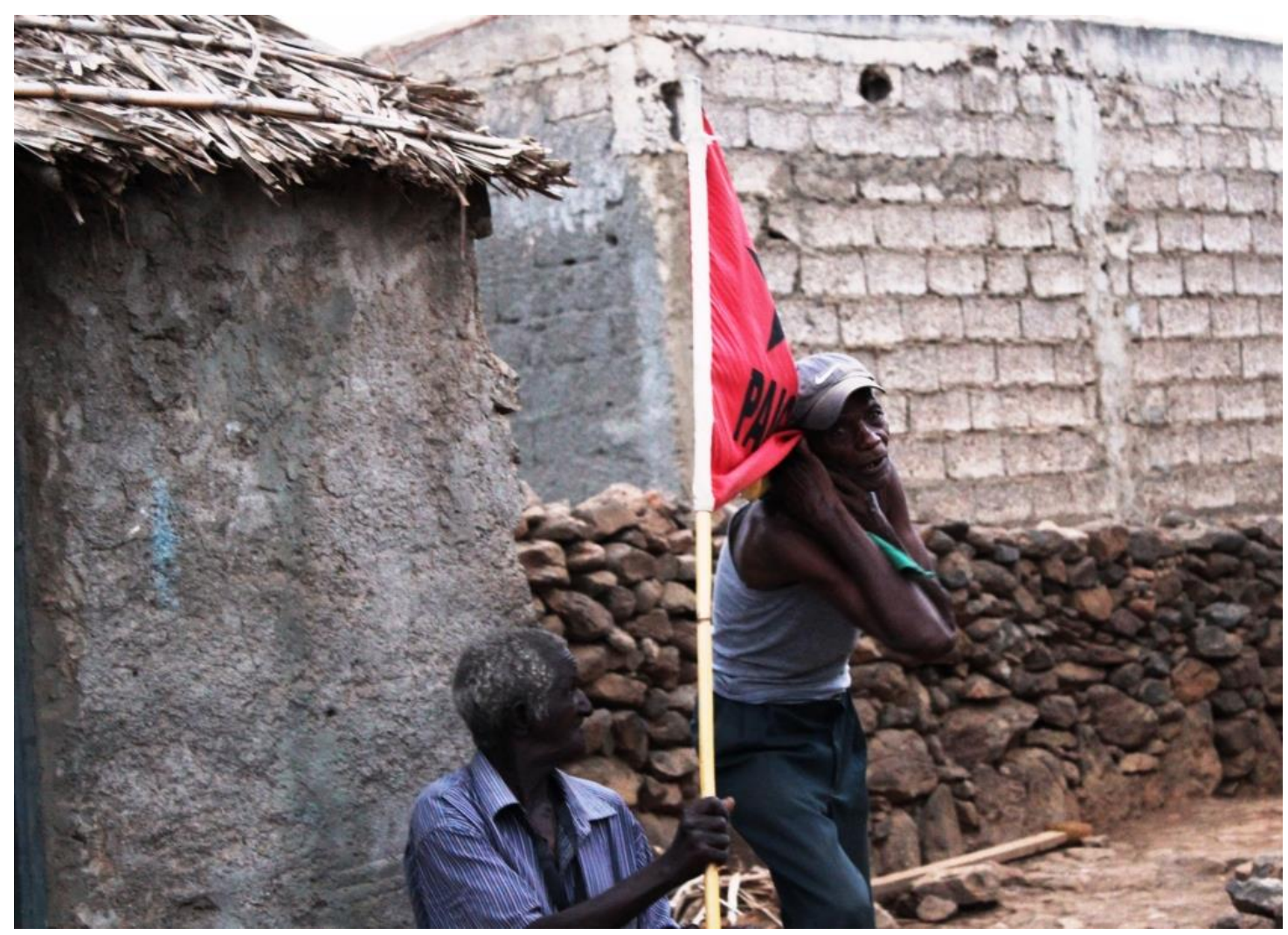

Felix e Domingos Guardiões das Tradições. Fonte: Hilton P. Silva.

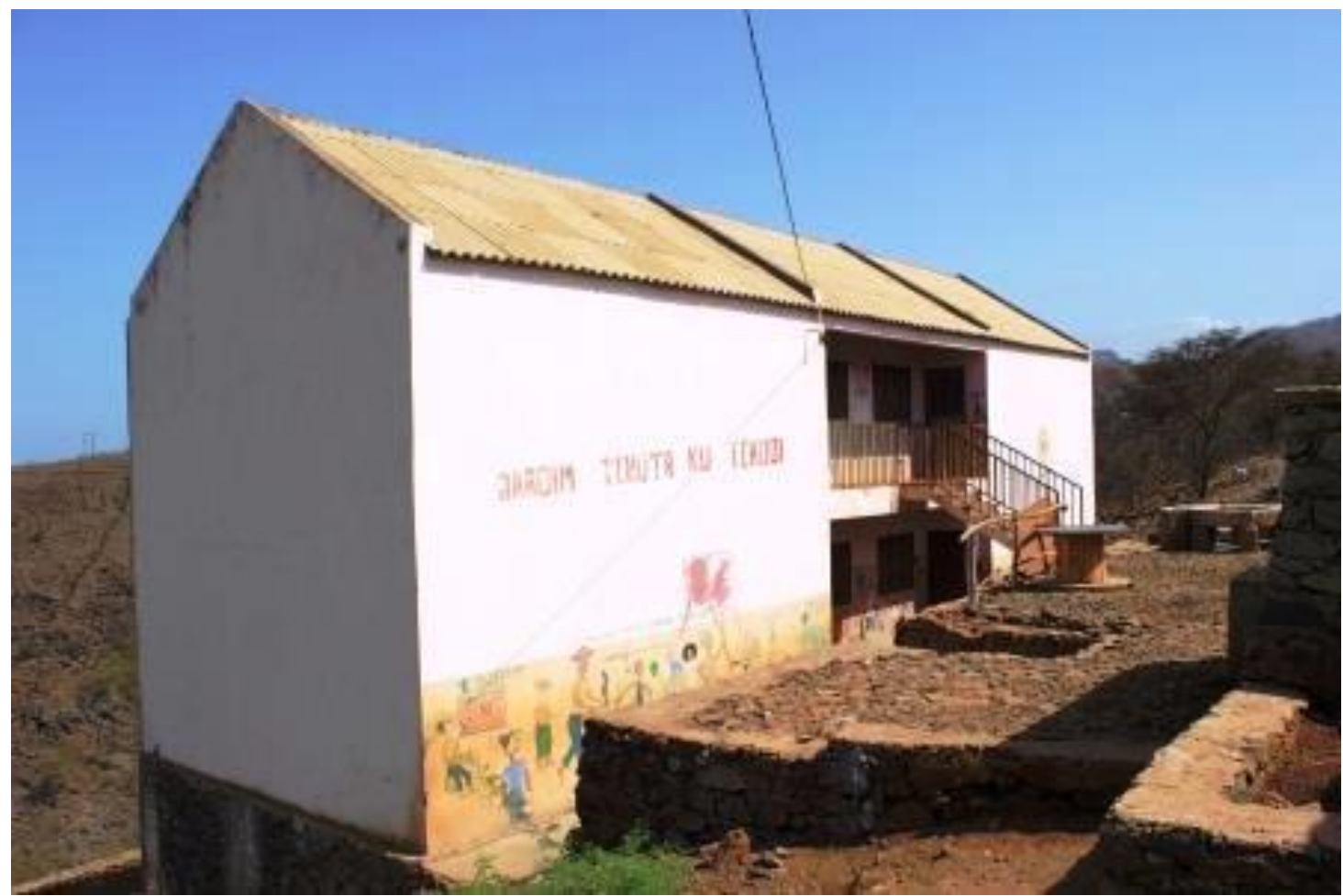

Escola na comunidade. Fonte: Hilton P. Silva.

Iluminuras, Porto Alegre, v. 17, n. 41, p. 340-358, jan/jun, 2016. 


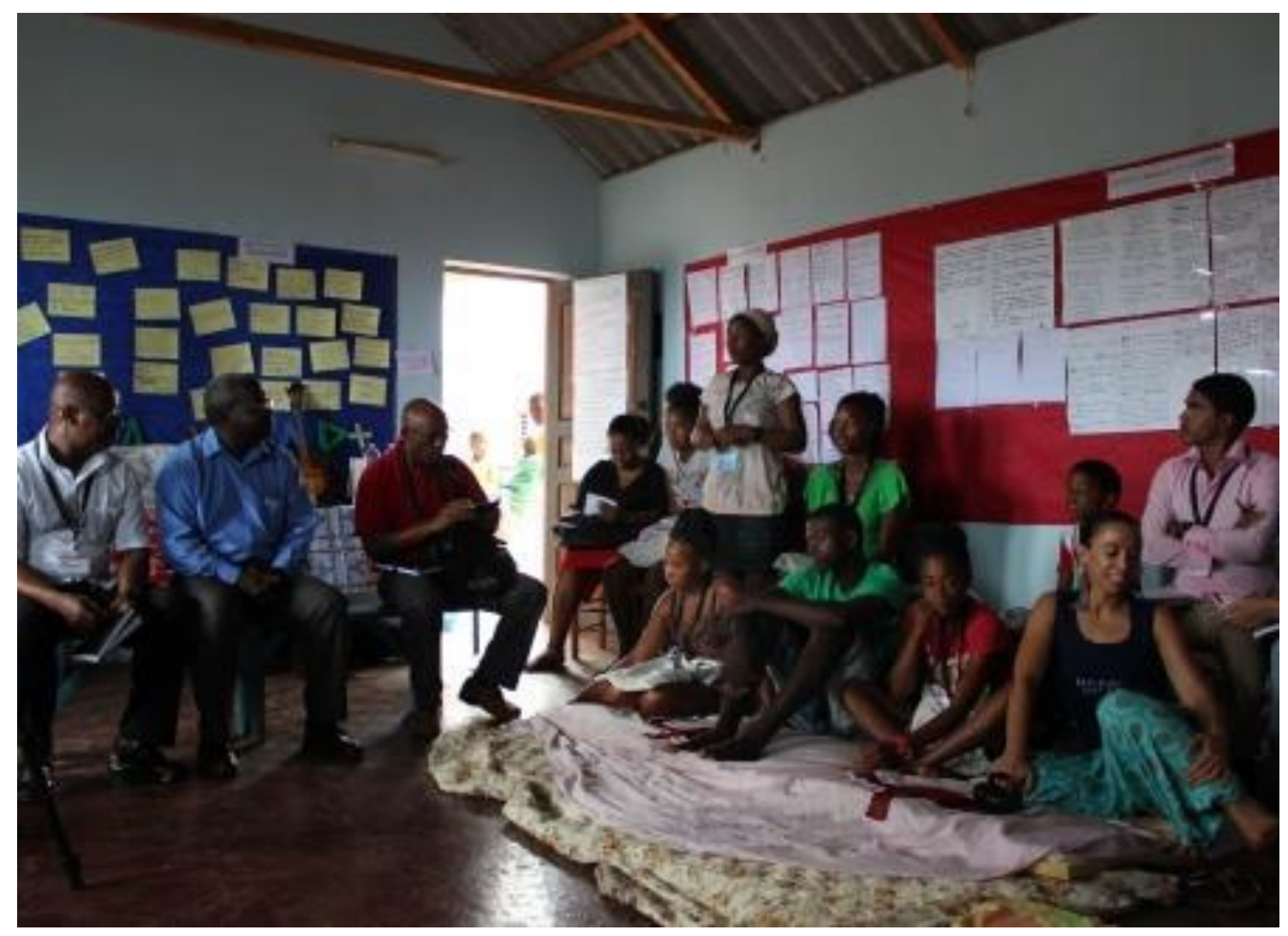

Zy fala na oficina da UPMS. Fonte: Hilton P. Silva.

As casas da comunidade permanecem tradicionais, feitas principalmente de palha e pedra (funcos ou presépios), sem encanamento ou qualquer tipo de saneamento ambiental. A água para o consumo de todos vem de uma cisterna que se abastece quando chove. Principalmente as meninas e mulheres, retiram e carregam baldes ao longo do dia para abastecer as residências. Logo ao raiar do sol mulheres, homens e crianças saem para as atividades agrícolas e voltam ao fim do dia com os alimentos coletados e a lenha para cozinhar. As cozinhas são ao lado ou atrás das casas e as mulheres são responsáveis pela preparação cotidiana dos alimentos. Os homens e os meninos trabalham principalmente no pastoreio das cabras e na pesca. Não há qualquer tipo de serviço de saúde no local, por isso, o conhecimento etnomédico e fitoterápico tem sido preservado, principalmente pelos mais idosos, e é intensamente utilizado por todos. As semelhanças com os quilombos estão por todas as partes, desde a histórica luta contra a opressão até a contínua batalha por autodeterminação e reconhecimento, desde o modo de construção das casas tradicionais de palha, com móveis esparsos, à 
intensa conexão e interdependência do ambiente natural, da ausência do Estado como prestador de serviços à busca dos jovens por educação, da preservação das músicas e tradições seculares à intensa e criativa produção artística atual, da resistência dos mais velhos ao consumismo ao anseio da juventude pela tecnologia, das dificuldades de acesso aos serviços básicos de saneamento e saúde ao intenso conhecimento e uso das plantas medicinais, as similaridades entre Rabelados e quilombolas estão em praticamente todos os aspectos do cotidiano.

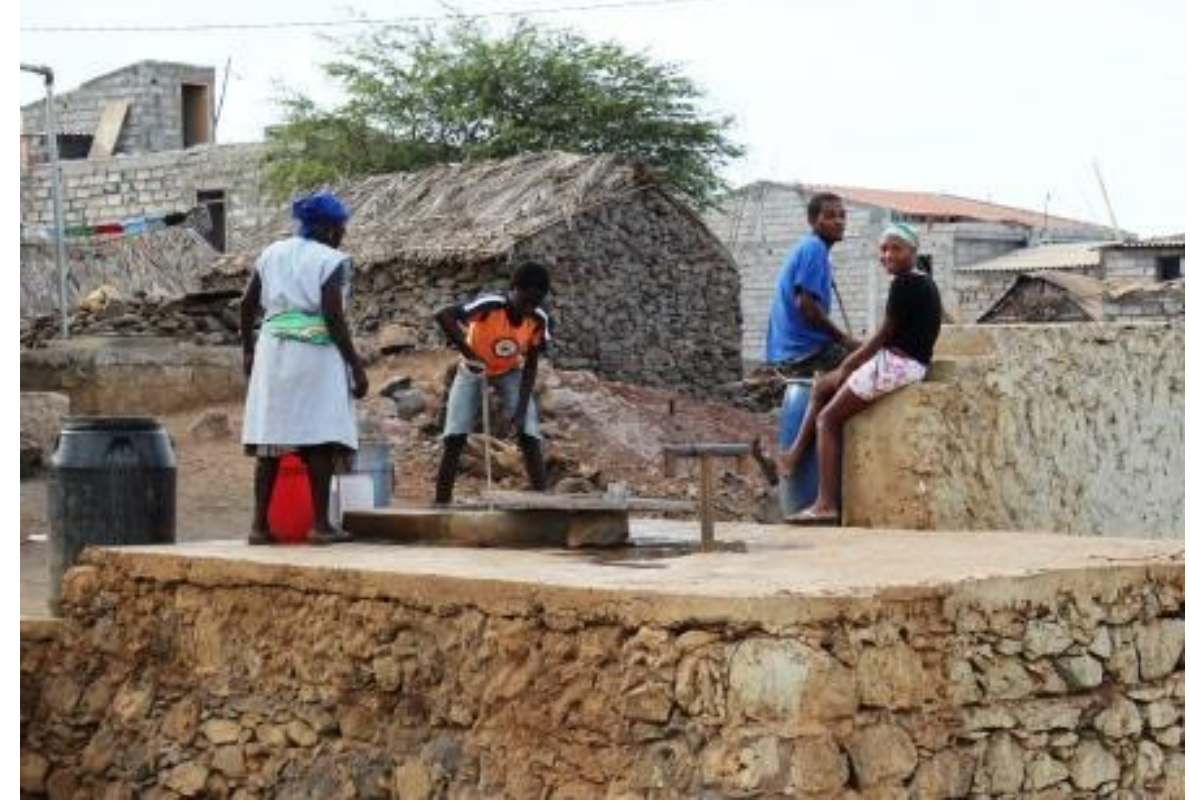

A cisterna da comunidade. Fonte: Hilton P. Silva.

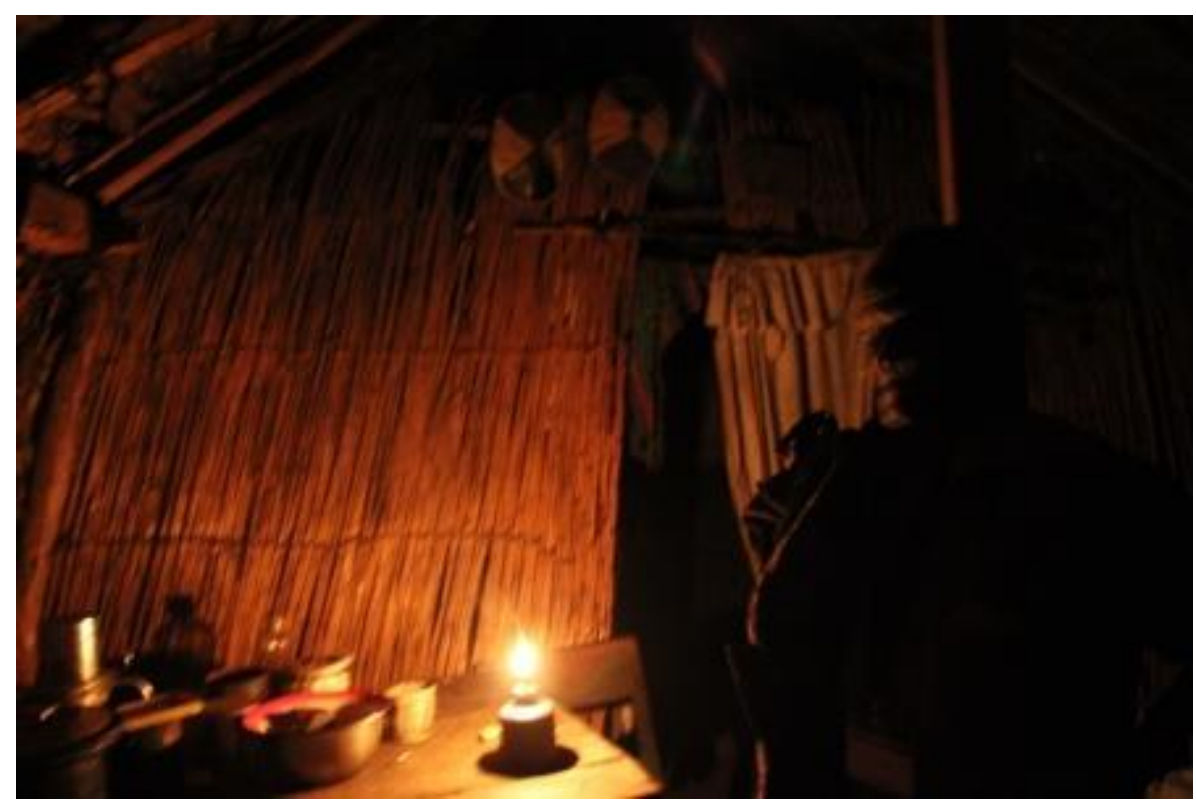

Interior da casa do seu Felix. Fonte: Hilton P. Silva.

Iluminuras, Porto Alegre, v. 17, n. 41, p. 340-358, jan/jun, 2016. 


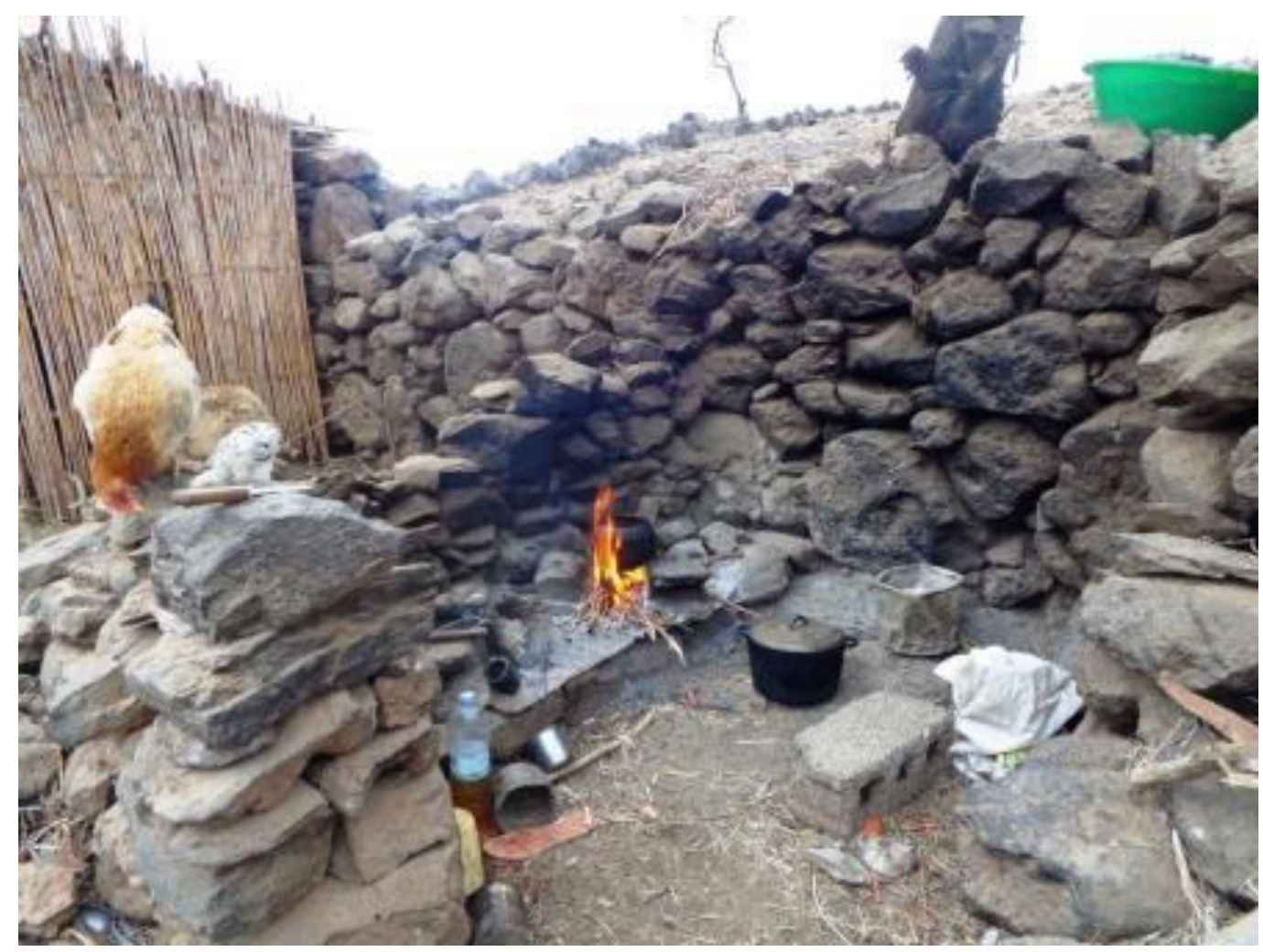

Uma cozinha na comunidade. Fonte: Hilton P. Silva.

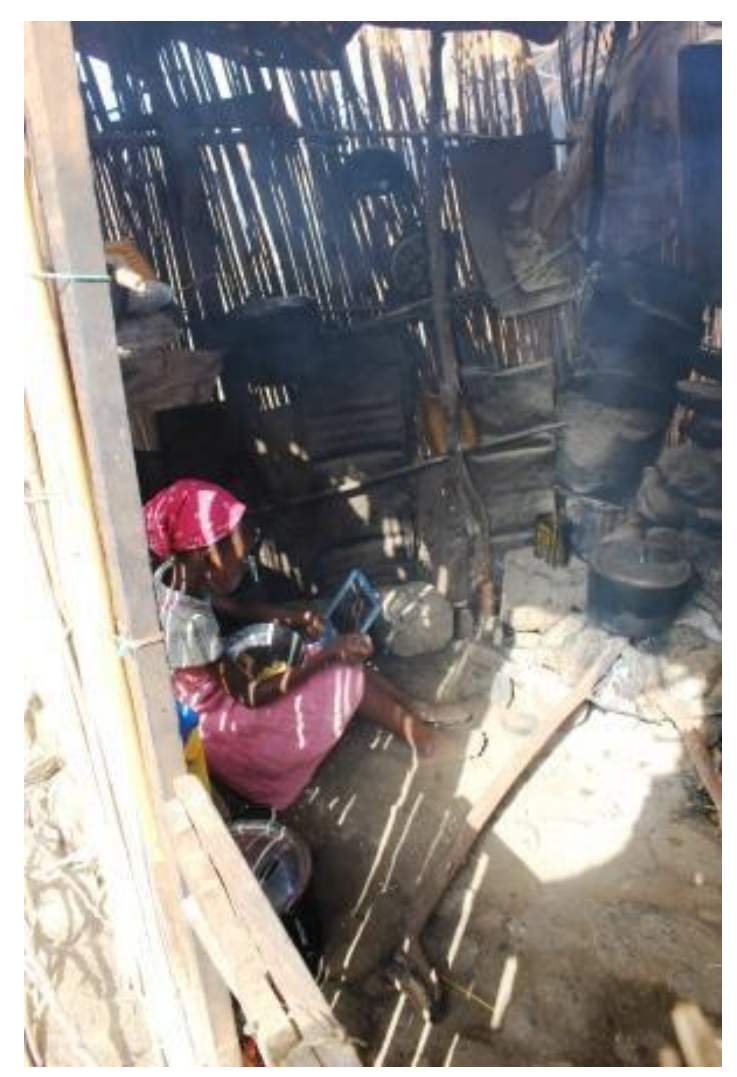

Menina cuidando da cozinha. Fonte: Hilton P. Silva. 


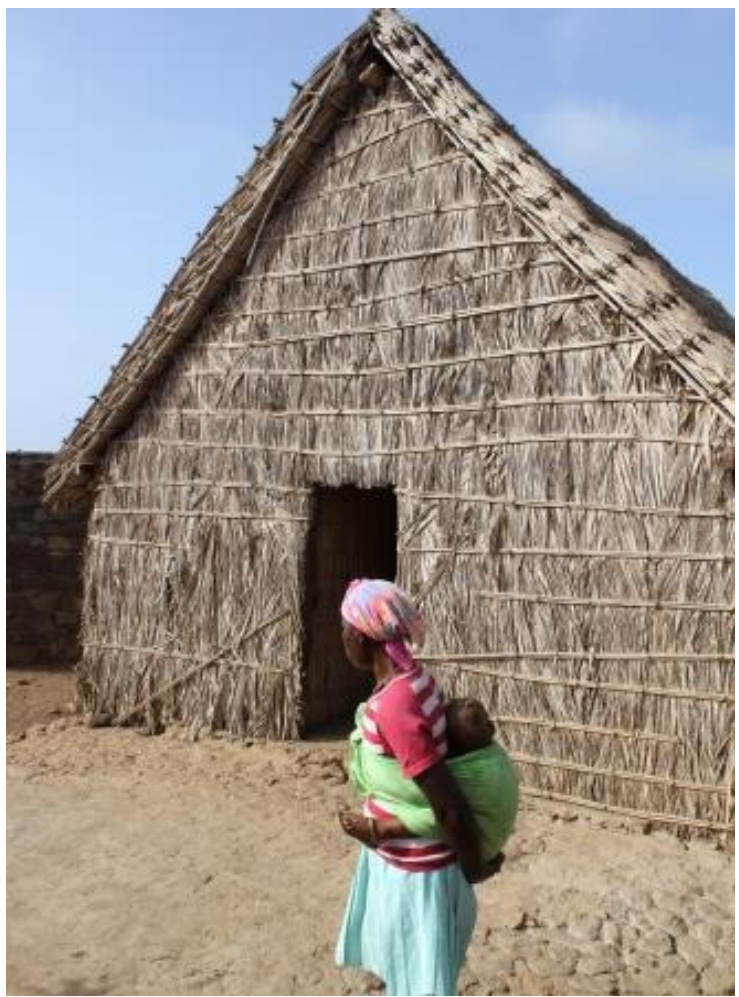

Mulher e bebe Rabelados. Fonte: Hilton P. Silva.

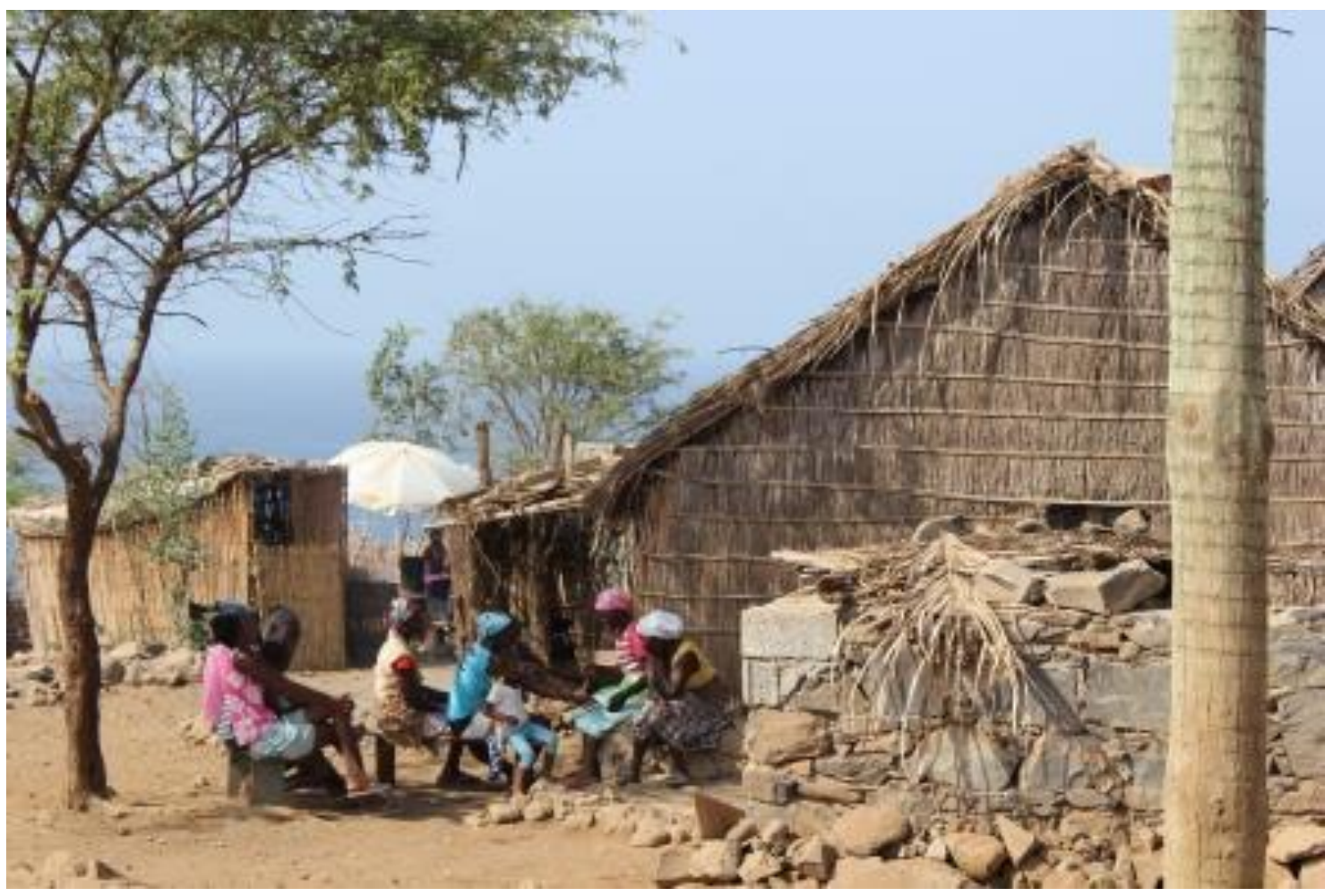

Reunião de mulheres Rabeladas. Fonte: Hilton P. Silva.

Iluminuras, Porto Alegre, v. 17, n. 41, p. 340-358, jan/jun, 2016. 


\section{Rabelados, Quilombolas e a Luta por Direitos}

Os indivíduos capturados em África, antes de vir para as Américas paravam em Cabo Verde, onde muitos eram batizados e passavam algum tempo em um processo de "aclimatação" ao cativeiro. Como o arquipélago não era habitado, os cabo-verdianos, como os quilombolas, tem sua ancestralidade no encontro de africanos e europeus, principalmente Portugueses. Mas o espírito de resistência nunca se apagou entre os que foram escravizados e, como no Brasil, muitos fugiam e se isolavam, eram caçados e lutavam. Seus descendentes se juntaram aos imigrantes coloniais portugueses, mas, como negros, continuaram a ser discriminados em seu próprio país. Assim como os remanescentes de quilombos, os Rabelados continuam a ser, em Cabo Verde, símbolos de resistência e espírito de independência, memória viva e dinâmica contra todas as formas de discriminação, segregação, e uma lembrança ao Estado do quanto ainda precisa ser feito para a inclusão social das populações rurais historicamente alijadas.

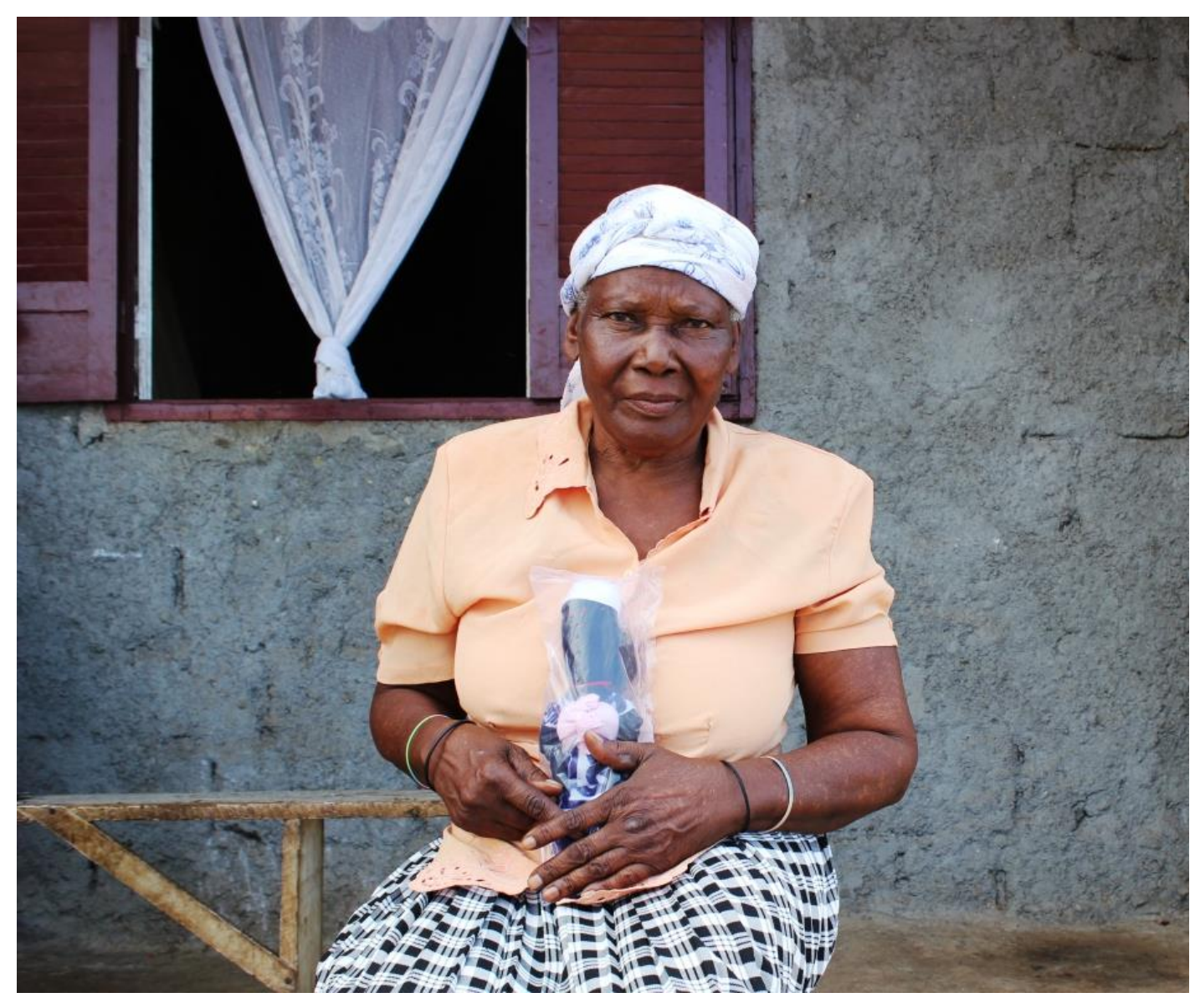

Dona Dea, artesanato e resistência. Fonte: Hilton P. Silva. 


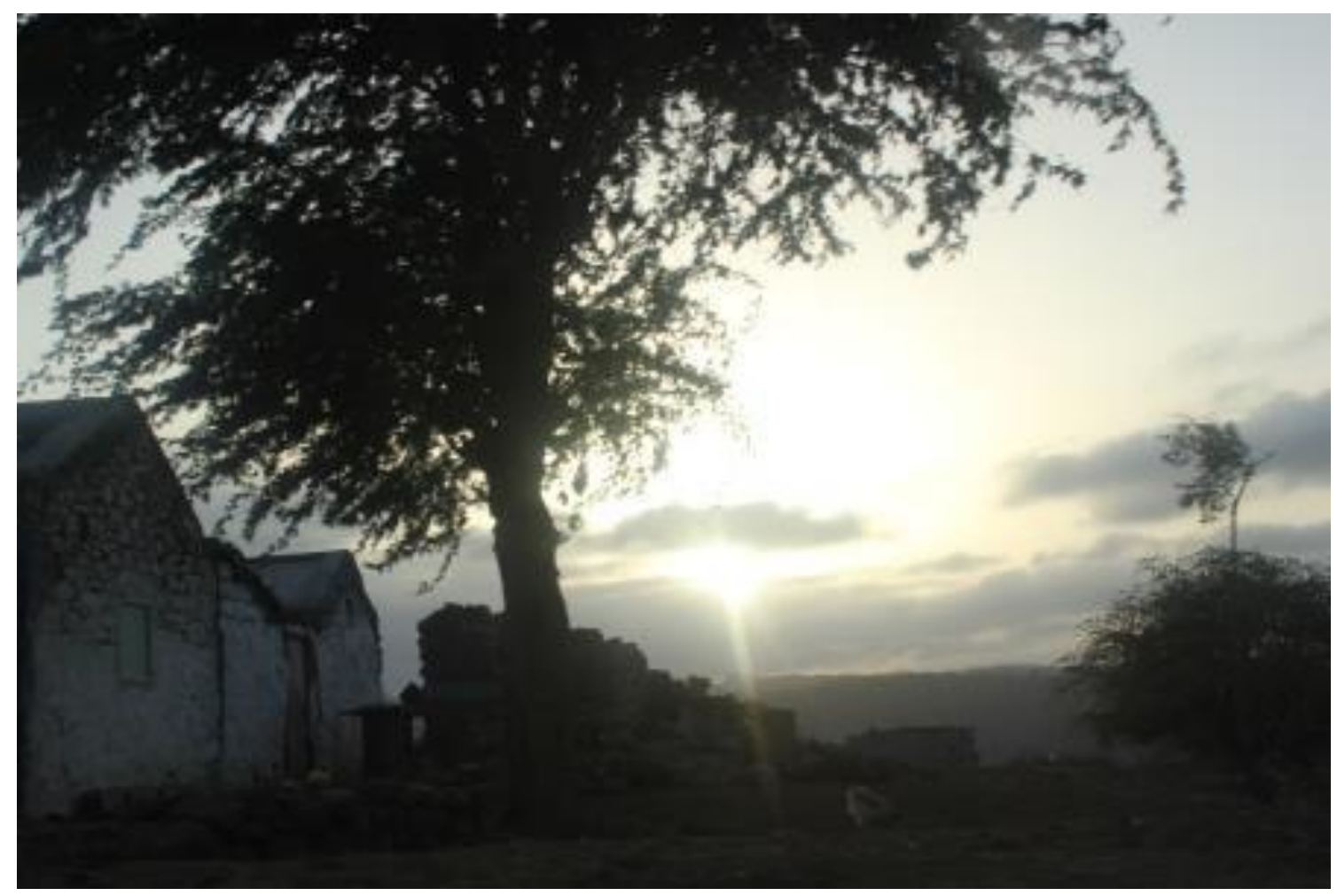

Pôr do sol na comunidade. Fonte: Hilton P. Silva. 


\section{Referências}

ASHER, F. Os Rabelados de Cabo Verde, História de uma Revolta. Paris: Harmattan, 2011.

ÉVORA, S.L. Comunicação global e cultura local. Indicadores Simbólicos sobre os Rabelados de Cabo Verde. Anuário Internacional de Comunicação Lusófona, p. 85-102, 2011.

JARAMILLO, D.R. Los Afroatlanticenses, Esclavización, Resistencia y Abolicion. Barranquilla: Universidad Simón Bolívar, 2009.

JÚNIOR, J.M. Os Rabelados de Santiago de Cabo Verde: Elementos para o estudo sociológico de uma comunidade. Lisboa: Sociedade Industrial Gráfica, 1974.

MONTEIRO, J. Os Rebelados da Ilha de Santiago de Cabo Verde. Praia: Centro de Estudos de Cabo Verde, 1974.

SALLES, V. O Negro no Pará sob o Regime de Escravidão. Belém: IAP: 2005.

SANTOS, B.S. A Universidade Popular dos Movimentos Sociais. In: Santos, Boaventura de Sousa, A Gramática do Tempo: Para uma Nova Cultura Política. Porto: Edições Afrontamento, 2006.

\section{Vídeos}

https://www.youtube.com/watch?v=v8dt91CSrTE

https://www.youtube.com/watch? $=$ =ZPnrzhiuFbE

https://www.youtube.com/watch?v=MHGYXM9pXEk

https://www.youtube.com/watch?v=zHgZIco4Y1w

Recebido em: 03/11/2015.

Aprovado em: 07/04/2016. 